\section{God lærebok i patologi}

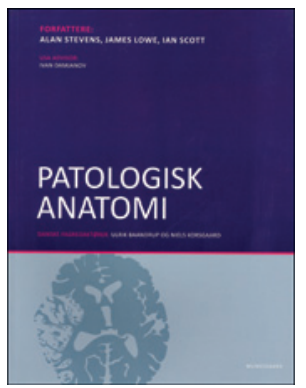

Alan Stevens, James Lowe, lan Scott

Patologisk anatomi

632 s, ill. København: Munksgaard Danmark 2012. Pris DKK 598

ISBN 978-87-628-0947-5

Denne læreboken er primært beregnet på medisinstudenter, men egner seg også for sykepleiestudenter og andre som arbeider $i$ helsevesenet. Forfatterne gjennomgår de sykdommene man som oftest møter i den kliniske hverdagen, og de gir et vesentlig bidrag til forståelsen av sykdommenes natur, diagnostikk og behandling. De 25 kapitlene er alle illustrert med gode figurer, bilder og tabeller.

Innledningsvis beskriver forfatterne grundig faget patologi, celleskade og vevsreaksjoner ved sykdom og observerte kliniske symptomer, fulgt av genetisk betingede sykdommer, neoplasi og grunnleggende immunpatologi. I de forskjellige organsystemenes patologi diskuterer de bakenforliggende patologisk-anatomiske prinsipper. Kapitlene er supplert med bokser som inneholder de viktigste grunnfakta og kliniske data. Illustrasjonene består av mer enn 800 fargebilder, figurer og tabeller av høy kvalitet som visualiserer de patologiske prosessene. Kapitlene avsluttes med kliniskpatologiske spørsmål basert på reelle pasienthistorier, og svarene finner man bakerst.

Til tross for de gode illustrasjonene og boksene er enkelte organers patologi for overfladisk beskrevet og heller ikke helt oppdatert. De senere årene har det skjedd en rivende utvikling innen finnålscytologi, kombinert med ultralydveiledning, noe som mangler i beskrivelsen av histopatologisk metode. Dette ser vi best i kapitlet om thyreoideasvulster hvor forfatterne skriver at bare histopatologisk undersøkelse av thyreoidearesektater kan diagnostisere solitært thyreoideakarsinom. De senere årenes utbredte tverrfaglige samarbeid i diagnoseteam har vist at cytologi kombinert med ultralyddiagnostikk har størst diagnostisk sikkerhet og erstatter kirurgi i mange tilfeller. Karsinom i prostata er den hyppigste kreftformen for menn. Denne kreftformen er summarisk beskrevet uten å legge vekt på grunnleggende histopatologisk diagnostikk eller fokusering på den spesielle tumorbiologien, som avspeiler den store hovedgruppen av klinisk benigne prostatakarsinomer på den ene siden og de aggressive, behandlingsresistente karsinomene på den andre siden. Den hyppigste kreftformen for kvinner, brystkreft, er derimot godt beskrevet med en god gjennomgang av prognostiske faktorer og spredningsmønster. I kapitlet diskuterer forfatterne også den nyere molekylære klassifikasjonen av mammakarsinom.

Boken er velskrevet og rikt illustrert og er lett å orientere seg i. Den har et godt og forståelig stikkordregister. I appendikset finner vi en god oversikt over de forskjellige laboratoriemetodene og terminologien. Her gir forfatterne gode råd for adekvat håndtering av vevsbehandling i laboratoriet. Boken vil være nyttig lesning for medisinstudenter og andre som interesserer seg for histopatologisk diagnostikk.

\section{Aasmund Berner}

Avdeling for patologi

Oslo universitetssykehus, Rikshospitalet

\section{Alternativ behandling i et antropologisk perspektiv}

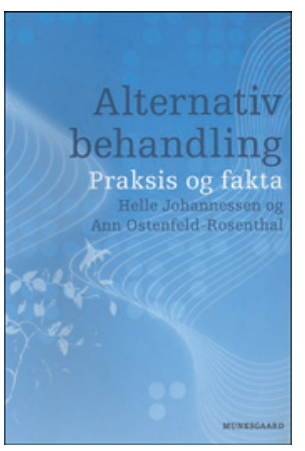

Helle Johannessen, Ann Ostenfeld-Rosenthal Alternativ behandling

Praksis og fakta. 132 s, tab, ill. København: Munksgaard Danmark, 2012. Pris DKK 178

ISBN 978-87-628-1092-1

Alternativ behandling er skrevet av to danske antropologer hvor særlig førsteforfatteren har lang erfaring innen forskning på alternativ behandling fra et samfunnsfaglig perspektiv. Boken er en nyttig, men overfladisk, gjennomgang av det alternative behandlingsfeltet. Søkelyset er naturlig nok rettet mot danske forhold, men temaet er relevant også for norske helsearbeidere.

Paperbacken har åtte tabeller og seks figurer, men mangler stikkordregister. Språket er lett tilgjengelig, selv for lesere utenfor den medisinske eller antropologiske profesjonen. Målgruppen oppgis til å være «professionelle og studerende inden for det etablerede sundhedssystem», men forfatterne oppgir ingen spesifikk hensikt utover «letlæselig og kortfattet introduktion til alternativ behandling». En rekke kasusbeskrivelser illustrerer de poengene forfatterne beskriver.

Temaene er presentert i 13 hovedkapitler med underkapitler. I de fire første hovedkapitlene gir forfatterne en bred bakgrunn for alternativ behandling med særlig utgangspunkt i danske forhold, mens de i hovedkapittel fem kort beskriver de fem vanligste behandlingsformene som er i bruk i Danmark. Dette samsvarer i grove trekk med det som er vanligst også i Norge.

I de fire neste hovedkapitlene drøfter forfatterne hvilke begrunnelser pasienter gir for å bruke alternativ behandling, og de setter opp rammemodeller for å forstå den utbredte bruken. Sentralt i forfatternes fremstilling står den narrative omredigeringen: «Narrativer er af mange medicinske antropologer blevet fremhævet som væsentlige i processen med at genskabe en meningsfyldt orden i det brud på mening, som en lidelse medfører, og dermed som væsentlige for at genskabe en forståelig verden for den enkelte.» Forfatterne mener at en slik omredigering er en sentral faktor som kan forklare hvor fornøyd pasientene er med alternative behandlere.

De siste fire hovedkapitlene omhandler effektforskning, regulering og fremtidsvyer. Her beskriver de kjente kritiske merknader mot den snevre bruken av det randomiserte, blindede kliniske forsøket innen effektforskning.

Effekten av alternative behandlinger kan være gjennom en fellesnevner som har med den rammen spesifikke behandlingsteknikker presenteres innen. Dette er det viktigste budskapet forfatterne bidrar med. Symbolverdien av teknikkene i seg selv bidrar trolig til denne kontekstuelle rammen. Det hele skaper for pasientene en forståelig og meningsfull historie, som kalles narrativ.

Forfatterne gir en utilstrekkelig orientering om den forskningsdokumenterte nytten av alternativ behandling generelt eller alternative behandlingsteknikker spesielt.

Den største svakheten er at forfatterne ikke berører mulige risikoer forbundet med alternativ behandling. Selv i akupunkturkapitlet nevner de ikke med et ord de kjente risikoene forbundet med akupunktur, og de hevder til og med at alternative behandlinger er «bivirkningsfrie». Dette skjemmer klart hovedinntrykket.

Vinjar Fønnebø

Nasjonalt forskningssenter innen komplementær og alternativ medisin Tromsø 